\title{
CELL BASED AFM BIOSENSENSING FOR SCREENING OF PULMONARY-DRUG RELATED ARRHYTMIC EFFECTS
}

\author{
1,2,3 Martin PESL, " Jan PRIBYL, ${ }^{4}$ Simon KLIMOVIC, ${ }^{5}$ Martin SCUREK, 1,2Deborah BECKEROVÁ, \\ ${ }^{5}$ Kristian BRAT, ${ }^{4,6}$ Petr SKLADAL, ${ }^{1,2}$ Vladimir ROTREKL \\ ${ }^{1}$ ICRC, St. Anna University Hospital, Czech Republic, EU \\ ${ }^{2}$ Department of Biology, Medical faculty, Masaryk University, Czech Republic, EU \\ ${ }^{3} 1^{\text {st }}$ Internal medicine clinic-Cardio-angiology, St. Anna University Hospital/Masaryk University, \\ Czech Republic, EU \\ ${ }^{4}$ Nanobiotechnology, CEITEC MU, Czech Republic, EU \\ ${ }^{5}$ Dept. of Respiratory Diseases, University Hospital Brno and Faculty of Medicine, Masaryk University, \\ Czech Republic, EU \\ ${ }^{6}$ Dept. of Biochemistry, Faculty of Science, Masaryk University, Czech Republic, EU
}

https://doi.org/10.37904/nanocon.2020.3745

\begin{abstract}
Atomic force microscopy (AFM) combined with stem cell derived human cardiomyocytes (CM) enables dynamic follow-up of cardiac contractions (e.g. beating rate, contraction and relaxation times), simultaneously with other CM biomechanical properties. Today, majority of drugs entering clinical usage needs to be tested for adverse arrhythmic effects; nevertheless, the effects on cardiomyocyte contraction are not routinely employed, only when related to cardiac pathologies. AFM-based biosensor allows in-vitro disease modeling, but also enables to monitor the effect of CM-contraction affecting drugs. Until today only few selected drugs modulating contractility and spontaneous pacing were described in animal models. This work for the first time demonstrates that basic biomechanical parameters, such as average value of contraction force and the beat rate, represent valuable pharmacological indicators of different phenotypic effects on cells without genetic burden. The presented method is robust and has low computational requirements, while keeping optimal spatial sensitivity (force detection limit $200 \mathrm{pN}$, corresponding to $20 \mathrm{~nm}$ displacement). The cardiac stimulating activities of drugs utilized in pneumology as aminophylline, ipratropium, and salbutamol were tested. Stimulating drugs, e.g. methylxanthines and caffeine, presented aberrant cardiomyocyte response, confirming arrhythmogenic potential, and force related fluctuations. Quantification of spontaneous contraction irregularities and related contractility changes allow precise scaling of potential negative effects adding new safety level to clinically relevant drug testing. AFM combined with human CMs serve as robust real-time screening platform for effects of pulmonary drugs. Here we describe changes in $\mathrm{CM}$ contractility, which is hard to describe by other screening methods and was never tested with described medication.
\end{abstract}

Keywords: Cardiomyocyte, contraction, arrhythmia, in vitro modeling, drug adverse events, pulmonary drugs

\section{INTRODUCTION}

There is large group of patients with chronic obstructive pulmonary disease (COPD) and bronchial asthma $(A B)$, receiving long-term/lifelong and combined bronchodilator (BD) treatment. Majority of commonly used drugs in this combination has certain influence on heart contractility and rhythm. The most prevalent drugs include methylxanthines, beta-2-sympathomimetics ( $\beta 2-S M)$, parasympatholytics, and inhaled or oral/intravenous corticosteroids $[1,2]$. 
Salbutamol, a $\beta 2-S M$, provides relief of shortness of breath and other symptoms for relatively short period of about six hours. Nevertheless, a number of cases of abuse was, reported due to its supposed anabolic effects and muscle performance enhancement [3-8]. Nowadays, there is a number of case studies and experimental body of evidence that during long-term BD treatment by $32-S M$, parasympatholytics and methylxanthines, some patients [or the substance abusers) develop cardiomyopathy (CMP), chronic heart failure (CHF), cardiac arrhythmia (CA) and even sudden cardiac death (as the first cardiac manifestation of CMP) [9-17].

Cellular and even cardiomyocyte (CM) interactions with BD drugs were studied and are well-known from animal models and primary CMs mixtures (homogenized animal hearts) [18,19]. Despite wide array of phenotypic assays available [20] human CMs have not yet been studied and it remains to be disclosed, how BD substances affect their physiological functions, especially contractility and rhythmicity.

Unique application of atomic force microscopy (AFM) as nanomechanical transducer combined with stem cell derived human CMs enables dynamic monitoring of cardiac contractions [21-23]. CMs beating rate, contraction and relaxation times and absolute force values can be recorded simultaneously with other relevant biomechanical properties [24]. Human CMs gain role in drug development, improving attrition rates [25], especially cardiotoxicity assays [26-29]. Adult human CMs, are not readily accessible from obvious reasons, still CMs can be differentiated from either human embryonic or induced pluripotent stem cells (hES and iPS, respectively) [30]. In this pilot work, we present an electromechanical in vitro system of 3D cardiac models and AFM together for drug testing in the format of an (organ) heart-on-a-chip. For this reason, we have used clinically relevant concentrations of selected drugs aminophylline (methylxanthine), salbutamol ( $\beta 2-\mathrm{SM})$ and ipratropium (parasympatholytic).

\section{METHODS}

The hES line CCTL14 derived and characterized at Masaryk University, Brno [31] was used. Cardiac differentiation was performed as previously described $[30,32,33]$ with minor modifications, resulting in $3 D$ spheroids of regular size and shape, called embryonic bodies (EB). AFM setup (JPK NanoWizard 3, JPK, Berlin, Germany), together with an inverted light microscope (IX-81S1F-3, Olympus, Tokyo, Japan), was employed to record mechanocardiograms of spontaneously contracting EBs as previously described [21-23]. The tested drugs were diluted to clinically relevant concentrations [19,34] and the resulting response curves were recoded after initial equilibration in Tyrode's solution, followed by sequenced exchanges of media with increasing drug concentrations.

Each measurement consisted of $10 \mathrm{~min}$ stabilization and $10 \mathrm{~min}$ measurement. The mechanical properties of beating EBs were expressed as force of contraction in $\mathrm{nN}(\mathrm{R}-\mathrm{S})$ as previously described [30]; however, the values were relativized for final comparison. Rhythmical properties were described as contractions/beats per minute (BPM). Statistical evaluation was carried out in GraphPad Prism 8.4.3 software (GraphPad Software, Inc., La Jolla, CA, USA). All data were tested for outliers by ROUT $(Q=1 \%)$ method, and available normality tests were performed. Contraction and force of EBs with different concentration of aminophylline was crosscompared by Brown-Forsythe ANOVA test, with Dunnett's T3 multiple comparison test. Due to single measured entity, statistics were not applied to salbutamol and ipratropium.

\section{RESULTS}

Pilot sets were measured for 12 clusters of CMs derived from hES cell line CCTL14. Total of 10 clusters were measured in four subsequent concentrations of aminophylline, nevertheless 3 of those exhibited aberrant behavior, previously described as stop-and go effect [23]. These were excluded from the pilot evaluation. Only pilot sets were measured for Salbutamol and Ipratropium (so far).

Force (RS) and BPMs were not significantly differing, probably due to small sample size; nevertheless, the observed trend has shown increased force and frequency for high concentrations (10 mM) of Aminophylline. 
Moreover, the initially compact set of contractions became highly variable. On the contrary, small Aminophylline concentrations $(10 \mu \mathrm{M})$ led to insignificant decrease of contractility and force. Details are depicted in Figure 1.

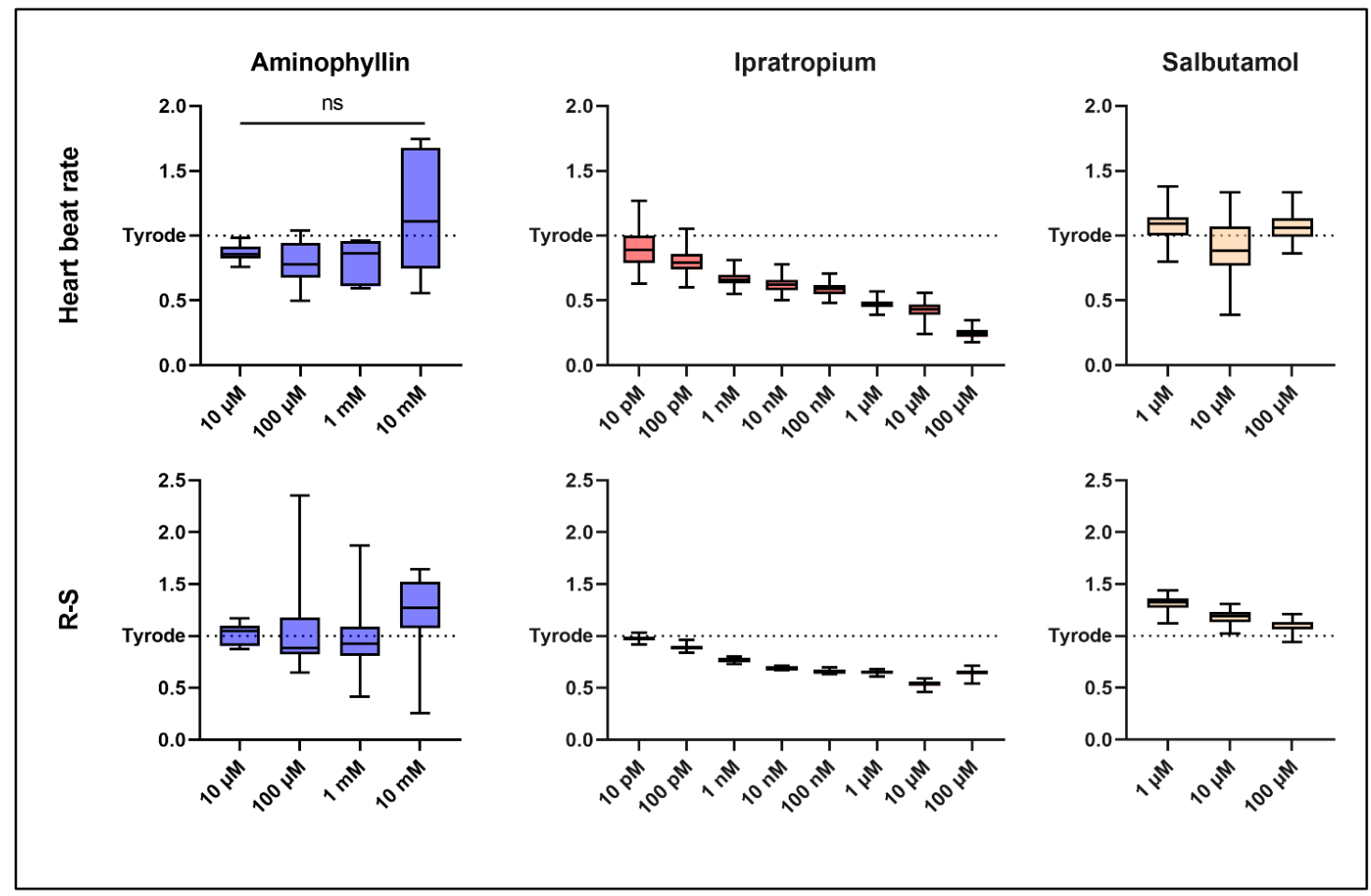

Figure 1 relativized force of contraction in $\mathrm{nN}(\mathrm{R}-\mathrm{S})$ contractions/beats per minute (BPM)

Salbutamol in pilot trial did not exhibit change in contraction rate, nevertheless small concentration of Salbutamol resulted in 1.5 fold increase in contractility, which negatively correlated with increasing concentration of the substance up to $100 \mu \mathrm{M}$.

Ipratropium showed sustained negative trend through all concentrations, in both contraction rate and force.

\section{DISCUSSION}

This pilot set of data has for the first time shown consistent trend in CMs behavior influenced by pulmonary drugs. The Aminophylline end-point function is a phosphodiesterase inhibitor; thus an increase of intracellular calcium levels should be present, contributing to positive inotropy [35]. Nevertheless, those changes can be also ascribed to direct catecholamine effect [36]. This limited set of data would support opinion, that Aminophylline does not significantly contribute to myocardial contractility [37]; however, it may have some role in increasing contraction rate and the effect on the regularity of contraction has to be further studied.

Salbutamol on the other hand has shown negative trend for inotropic response, which is in contrast with positive inotropic effect in animals (guinea pig and dog), despite describing lower-than-Isoprenaline effect [38]. Difference may be attributed to lower concentrations used in animal experiments (less than $10 \mu \mathrm{M}$ ), which may correspond to the first (ascending) part of contractility curve. Here may be shown the same, but descending part of curve, after reaching maximal inotropic effect of the substance. Chronotropic effect of Salbutamol was ascribed to atrioventricular (AV) nodal increased conduction [39,40], rather than sinoatrial node (SA). Increase of the beating frequency in the whole organ can also relate to lower refractory period in the large piece of tissue, enabling easier arrhythmia occurrence and spreading [40]. Nevertheless, its direct effect on SA node is very small compared to AV node and this seems to be also irrelevant to the $3 \mathrm{D}$ CM model of small scale, 
where the spontaneous contractions are independent of conductive system. Increase in rhythm of contraction cannot be traced in the pilot Salbutamol dataset.

Positive chronotropic effect of ipratropium is attributed to decrease of parasympathetic vagal stimulation, typical for anticholinergic drugs $[41,42]$. One work described a small decrease of contraction frequency due to other muscarinic agonist (Tiotropium), Although no significant change was traced directly to ipratropium [43] Contrary to this, we have observed sustained decreased chronotropic and inotropic effects of the substance; further investigation has to expand the number of samples and provide more data beyond the pilot experiment.

\section{CONCLUSION}

This pilot set confirmed that AFM-based nanomechanical system combined with cardiomyocytes can serve as a robust screening platform for direct drug effects, especially myocardial contractility, which is hard to describe by other screening methods. Pulmonary drugs with stimulating properties such as aminophylline, presented aberrant cardiomyocyte response in this context. This is a clear sign of arrhythmogenic potential of distinct compounds. Moreover, force related fluctuations were present in pilot data in vitro. Spontaneous contraction irregularities quantification and related contractility changes allow precise scaling of potential negative effects, adding new safety level to subsequent clinically relevant drug testing.

\section{ACKNOWLEDGEMENTS}

Supported by Ministry of Health of the Czech Republic, grant AZV NU20-06-00156, we acknowledge
CF Nanobiotechnology supported by MEYS CR (LM2018127).

Supported by the project no. LQ1605 from the National Program of Sustainability II (MEYS CR) project FNUSA-ICRC and Supported by the European Regional Development Fund - Project ENOCH (No. CZ.02.1.01/0.0/0.0/16_019/0000868). Supported by Ministry of Health of the Czech Republic (MH CZ-DRO FNBr 65269705). Martin Pesl was supported by "Junior researcher 2020" scheme, Medical faculty, Masaryk University.

\section{REFERENCES}

[1] POlVERINO, F., SAM, A., GUERRA, S. COPD: To Be or Not to Be, That is the Question. Am J Med. 2019, vol. 132, no. 11, pp.1271-8.

[2] ZINELLU, E., PIRAS, B., RUZITTU, G..GM., FOIS, S.S., FOIS, A.G., PIRINA, P. Recent Advances in Inflammation and Treatment of Small Airways in Asthma. Int J Mol Sci. 2019, vol. 20, no. 11, p. 2617.

[3] COLLOMP, K., CANDAU, R., LASNE, F., LABSY, Z., PRÉFAUT, C., DE CEAURRIZ, J. Effects of short-term oral salbutamol administration on exercise endurance and metabolism. J Appl Physiol. 2000, vol. 89, no. 2, pp.430-6.

[4] VAN BAAK, M.A., MAYER, L.H., KEMPINSKI, R.E., HARTGENS, F. Effect of salbutamol on muscle strength and endurance performance in nonasthmatic men. Med Sci Sports Exerc. 2000 Jul, vol. 32, no. 7, pp. 1300-6.

[5] Le PANSE, B., ARLetTAZ, A., PORTIER, H., LECOQ, A-M., DE CEAURRIZ, J., COLLOMP, K. Short term salbutamol ingestion and supramaximal exercise in healthy women. Br J Sports Med. 2006 Jul, vol. 40, no. 7, pp. 627-31.

[6] MARTINEAU, L., HORAN, M.A., ROTHWELL, N.J., LITTLE, R.A. Salbutamol, a beta 2-adrenoceptor agonist, increases skeletal muscle strength in young men. Clin Sci (Lond). 1992, vol. 83, no. 5, pp. 615-21.

[7] BAILEY, J., COLAHAN, P., KUBILIS, P., PABLO, L. Effect of inhaled beta 2 adrenoceptor agonist, albuterol sulphate, on performance of horses. Equine Vet J Suppl. 1999, no. 30, pp. 575-80.

[8] BOUCHER, A., PAYEN, C., GARAYT, C., IBANEZ, H., DIENY, A., DOCHE, C., et al. Salbutamol misuse or abuse with fatal outcome: a case-report. Hum Exp Toxicol. 2011 Nov, vol. 30, no. 11, pp. 1869-71. 
[9] COUGHLIN, S.S., METAYER, C., MCCARTHY, E.P., MATHER, F.J., WALDHORN, R.E., GERSH, B.J., et al. Respiratory illness, beta-agonists, and risk of idiopathic dilated cardiomyopathy. The Washington, DC, Dilated Cardiomyopathy Study. Am J Epidemiol. 1995 Aug 15, vol. 142, no. 4, pp. 395-403.

[10] BOUVY, M.L., HEERDINK, E.R., DE BRUIN, M.L., HERINGS, R.M., LEUFKENS, H.G., HOES, A.W. Use of sympathomimetic drugs leads to increased risk of hospitalization for arrhythmias in patients with congestive heart failure. Arch Intern Med. 2000 Sep 11, vol. 160, no. 16, pp. 2477-80.

[11] CAZZOLA, M., SANTUS, P., D'ADDA, A., PIZZOLATO, S., DI MARCO, F., CENTANNI, S. Acute effects of higher than standard doses of salbutamol and ipratropium on tiotropium-induced bronchodilation in patients with stable COPD. Pulm Pharmacol Ther. 2009 Jun, vol. 22, no. 3, pp. 177-82.

[12] MAAK, C.A., TABAS, J.A., MCCLINTOCK, D.E. Should acute treatment with inhaled beta agonists be withheld from patients with dyspnea who may have heart failure? J Emerg Med. 2011 Feb, vol. 40, no.2, pp. $135-45$.

[13] ABRAMSON, M.J., WALTERS, J., WALTERS, E.H. Adverse effects of beta-agonists: are they clinically relevant? Am J Respir Med. 2003, vol. 2, no. 4, pp. 287-97.

[14] MEYER, M.F., HOPKINS, W.E., KAMINSKY, D.A. Cardiovascular collapse in a 77-year-old-woman with an asthma exacerbation following bronchodilator treatment. Chest. 2003 Sep, vol. 124, no. 3, pp. 1160-3.

[15] JENNE, J.W. Can oral beta2 agonists cause heart failure? Lancet. 1998, vol. 352, no.9134, pp. $1081-2$.

[16] TOMLIN, A.M., WOODS, D.J., LLOYD, H.S., STEWART, R.A.H., TILYARD, M.W. Understanding medicines with a propensity to increase the risk of heart failure: Combining existing knowledge with targeted population assessment. Pharmacoepidemiol Drug Saf. 2018, vol. 27, no. 9, pp. 1019-28.

[17] SAY, B., DEGIRMENCIOGLU, H., GOZDE KANMAZ KUTMAN, H., URAS, N., DILMEN, U. Supraventricular tachycardia after nebulized salbutamol therapy in a neonate: case report. Arch Argent Pediatr. 2015 Apr, vol. 113, no. 2, pp. e98-100.

[18] WANG, Y., YUAN, J., QIAN, Z., ZHANG, X., CHEN, Y., HOU, X., et al. $\beta 2$ adrenergic receptor activation governs cardiac repolarization and arrhythmogenesis in a guinea pig model of heart failure. Sci Rep. 2015 Jan 8, vol.5, p. 7681.

[19] SIEDLECKA, U., ARORA, M., KOLETTIS, T., SOPPA, G.K..R, LEE, J., STAGG, M.A., et al. Effects of clenbuterol on contractility and $\mathrm{Ca} 2+$ homeostasis of isolated rat ventricular myocytes. Am J Physiol Heart Circ Physiol. 2008 Nov, vol. 295, no. 5, pp. H1917-1926.

[20] PESL, M., PRIBYL, J., CALUORI, G., CMIEL, V., ACIMOVIC, I., JELINKOVA, S., et al. Phenotypic assays for analyses of pluripotent stem cell-derived cardiomyocytes. Journal of Molecular Recognition. 2017, vol. 30, no. 6.

[21] PRIBYL, J., PEŠL, M., CALUORI, G., ACIMOVIC, I., JELINKOVA, S., DVORAK, P., et al. Biomechanical Characterization of Human Pluripotent Stem Cell-Derived Cardiomyocytes by Use of Atomic Force Microscopy. Methods Mol Biol. 2019, vol. 1886, pp. 343-53.

[22] CALUORI, G., PRIBYL, J., CMIEL, V., PESL, M., POTOCNAK, T., PROVAZNIK, I., et al. Simultaneous study of mechanobiology and calcium dynamics on hESC-derived cardiomyocytes clusters. J Mol Recognit. 2019 Feb, vol. 32, no. 2, p. e2760.

[23] PESL, M., PRIBYL, J., ACIMOVIC, I., VILOTIC, A., JELINKOVA, S., SALYKIN, A., et al. Atomic force microscopy combined with human pluripotent stem cell derived cardiomyocytes for biomechanical sensing. Biosensors and Bioelectronics. 2016, vol. 85, pp. 751-7.

[24] CHEN, A.T., ZOU, S. Evaluation of drug-mediated arrhythmic changes in spontaneous beating cardiomyocytes by AFM. Analyst. 2016 Nov 21, vol. 141, no. 22, pp. 6303-13.

[25] SINNECKER, D., LAUGWITZ, K-L., MORETTI, A. Induced pluripotent stem cell-derived cardiomyocytes for drug development and toxicity testing. Pharmacology \& Therapeutics. 2014 Aug, vol. 143, no. 2, pp. 246-52.

[26] TAKEDA, M., MIYAGAWA, S., FUKUSHIMA, S., SAITO, A., ITO, E., HARADA, A., et al. Development of In Vitro Drug-Induced Cardiotoxicity Assay by Using Three-Dimensional Cardiac Tissues Derived from Human Induced Pluripotent Stem Cells. Tissue Engineering Part C: Methods. 2017 Oct 1, vol. 24, no. 1, pp. 56-67.

[27] ACIMOVIC, I., VILOTIC, A., PESL, M., LACAMPAGNE, A., DVORAK, P., ROTREKL, V., et al. Human pluripotent stem cell-derived cardiomyocytes as research and therapeutic tools. Biomed Res Int. 2014, vol. 2014, p. 512831. 
[28] BRAAM, S.R., TERTOOLEN, L., VAN DE STOLPE, A., MEYER, T., PASSIER, R., MUMMERY, C.L. Prediction of drug-induced cardiotoxicity using human embryonic stem cell-derived cardiomyocytes. Stem Cell Research. 2010 Mar 1, vol. 4, no. 2, pp. 107-16.

[29] CONG, Y., HAN, X., WANG, Y., CHEN, Z., LU, Y., LIU, T., et al. Drug Toxicity Evaluation Based on Organ-on-achip Technology: A Review. Micromachines (Basel). 2020 Apr 3, vol. 11, no. 4.

[30] PESL, M., ACIMOVIC, I., PRIBYL, J., HEZOVA, R., VILOTIC, A., FAUCONNIER, J., et al. Forced aggregation and defined factors allow highly uniform-sized embryoid bodies and functional cardiomyocytes from human embryonic and induced pluripotent stem cells. Heart Vessels. 2014 Nov, vol. 29, no. 6, pp. 834-46.

[31] ADEWUMI, O., AFLATOONIAN, B., AHRLUND-RICHTER, .L, AMIT, M., ANDREWS ,P.W., et al. Characterization of human embryonic stem cell lines by the International Stem Cell Initiative. Nat Biotechnol. 2007 Jul, vol. 25, no. 7, pp. 803-16.

[32] KRUTÁ, M., ŠENEKLOVÁ, M., RAŠKA, J., SALYKIN, A., ZERZÁNKOVÁ, L., PEŠL, M., et al. Mutation frequency dynamics in HPRT locus in culture-adapted human embryonic stem cells and induced pluripotent stem cells correspond to their differentiated counterparts. Stem Cells Dev. 2014 Oct 15, vol. 23, no. 20, pp. 2443-54.

[33] JELINKOVA S, VILOTIC A, PRIBYL J, AIMOND F, SALYKIN A, ACIMOVIC I, et al. DMD Pluripotent Stem Cell Derived Cardiac Cells Recapitulate in vitro Human Cardiac Pathophysiology. Front Bioeng Biotechnol. [online]. 2020. Available from: https://doi.org/10.3389/fbioe.2020.00535.

[34] HARVEY, K.L., HUSSAIN, A., MADDOCK, H.L. Ipratropium bromide-mediated myocardial injury in in vitro models of myocardial ischaemia/reperfusion. Toxicol Sci. 2014 Apr, vol. 138, no. 2, pp. 457-67.

[35] COLUCCI, W.S., WRIGHT, R.F., BRAUNWALD, E. New positive inotropic agents in the treatment of congestive heart failure. Mechanisms of action and recent clinical developments. 2. N Engl J Med. 1986 Feb 6, vol. 314, no. 6, pp. 349-58.

[36] SPALDING, M. The hemodynamic effects of aminophylline, adenosine, losartan and nitric oxide administered shortly after right heart infarct in a porcine model. [online]. Oulu; 2001 [cited 2020 Oct 20]. Available from: http://jultika.oulu.fi/files/isbn9514264010.pdf

[37] ELLIOTT, C.G., NIETRZEBA, R.M., ADAMS, T.D., CRAPO, R.O., JENSEN, R.L., YANOWITZ, F.G.. Effect of intravenous aminophylline upon the incremental exercise performance of healthy men. Respiration. 1985, vol. 47, no. 4, pp. 260-6.

[38] HUGHSON, R.L., LEDSOME, J.R. The Inotropic and Chronotropic Responses of the Guinea Pig and Dog Myocardium to Isoprenaline and Salbutamol. Can J Physiol Pharmacol. 1975 Apr 1, vol. 53, no. 2, pp. 231-8.

[39] KALLERGIS, E.M., MANIOS, E.G., KANOUPAKIS, E.M., SCHIZA, S.E., MAVRAKIS, H.E., KLAPSINOS, N.K., et al. Acute Electrophysiologic Effects of Inhaled Salbutamol in Humans. CHEST. 2005 Jun 1, vol. 127, no. 6, pp. 2057-63.

[40] INSULANDER, P., JUHLIN-DANNFELT, A., FREYSCHUSS, U., VALLIN, H.. Electrophysiologic effects of salbutamol, a beta2-selective agonist. J Cardiovasc Electrophysiol. 2004 Mar, vol. 15, no. 3, pp.316-22.

[41] VAN VLYMEN, J.M., PARLOW, J.L. The effects of reversal of neuromuscular blockade on autonomic control in the perioperative period. Anesth Analg. 1997 Jan, vol. 84, no. 1, pp. 148-54.

[42] SINGH, S., LOKE, Y.K., ENRIGHT, P., FURBERG, C.D. Pro-arrhythmic and pro-ischaemic effects of inhaled anticholinergic medications. Thorax. 2013 Jan, vol. 68, no. 1, pp.114-6.

[43] SUBE R, ERTEL EA. Cardiomyocytes Derived from Human Induced Pluripotent Stem Cells: An In-Vitro Model to Predict Cardiac Effects of Drugs. JBiSE. 2017, vol. 10, no. 11, pp. 527-49. 